\title{
POVERTY REDUCTION IN COASTAL COMMUNITY AREA THROUGH MARINE TOURISM DEVELOPMENT: A CASE STUDY OF PEMUTERAN VILLAGE
}

\author{
Kadek Oka Erapartiwi. \\ Program Studi Kajian Pariwisata. \\ Universitas Udayana \\ erapartiwi@gmail.com
}

\begin{abstract}
This study investigates marine tourism's contribution to poverty reduction amongst communities living in the coastal area. The study mainly employed a qualitative research design and data were collected through a mixed-method approach involving interviews with a wide range of community members directly involved with tourism and observation. Some data were also gathered from secondary sources. The findings indicate that marine tourism brought benefits and played an important role in improving the living conditions of the poor in Pemuteran village. The study also identified several problems existing within the coastal community. Some of these barriers included lack of having adequate English from the villagers who are mostly traditional fishermen and lack broad-based management structures. The study concludes that marine tourism has the potential to contribute to poverty reduction in Pemuteran village. This can only happen if there is a unity of purpose and renewed cooperation amongst all tourism stakeholders, transparency, and accountability in financial matters.
\end{abstract}

Keywords: Poverty reduction, tourism, coastal communities,

\section{INTRODUCTION}

The provincial government of Bali still relies on the tourism sector, especially the provision of accommodation services to support the regional economy. Referring to the Bali provincial statistics (2018), Bali's total economy in quarter III-2018 which is measured based on Gross Regional Domestic Product (GDP) on the basis of current prices (ADHB) reaches Rp. 60.91 trillion. Bali Economic Quarter III-2018 compared to Quarter III-2017 grew by 6.24 percent. In terms of the business sector, the highest growth was recorded in the Construction business field at 11.77 percent. Bali's economy in the third quarter of 2018 is still dominated by businesses providing accommodation and food and beverages with a contribution of 23.13 percent followed by agriculture, forestry, and fisheries, which recorded 14.03 percent. Tourism plays an important role in terms of tourism contribution to the Gross Regional Domestic Product (GRDP) and employment. 
The increase of tourist visits to Bali turned out to have an indirect effect on the contribution of this sector to the GRDP.

Tourism has become an industry in Bali, which is a small province and lacks natural resources as in several other regions in Indonesia. The area of Bali Province is only $0.29 \%(5,632.86 \mathrm{~km} 2)$ of the total area of Indonesia with a population of more than 4.5 million. The Bali Provincial Government has set three leading developments, namely: Agriculture in the broad sense, small industries, and household crafts, as well as tourism. The government seeks to make these three priorities move forward simultaneously to become the locomotive of Bali's development. Geographically and demographically, Bali has a variety of cultures and a natural landscape. The beauty of nature and the unique and interesting diversity of culture then attract domestic and foreign tourists. The rapid development of Bali tourism has made Bali's economic structure to be very specific and has its own characteristics compared to other provinces in Indonesia. This is because the Balinese economy is built by relying on the tourism industry as the leading sector that has been able to encourage changes in the structure of the Bali Regional economy.

The alternative to alleviating poverty through tourism has long been a hot topic that provides hope for people's welfare and evenly distributed economic movements. The following are described several relevant journals on similar issues, one of which is from Rukendi (2008) entitled Tackling Poverty Through Sustainable Agro Tourism and Rural Tourism. In this journal, the author emphasizes that poverty should have been able to be overcome based on the Millennium Development Goals as agreed by all countries in the world through the United Nations (UN), including Indonesia. The main focus of his research is how the synergy of tourism and agriculture in the development of tourism products must be done with sustainable tourism and the pro-poor tourism paradigm. Then given a real example of the implementation of subak agro-tourism in Jatiluwih Tabanan and Tanjung Yogyakarta Tourism Village, which greatly reflects the implementation of Community-based tourism. This research suggests that Community-based tourism is very effective to improve the welfare of farmers while maintaining the sustainability and sustainability of the natural environment, the socio-cultural system of the community and the local economy without exploiting large energy resources.

More specific research is from Zapata et al (2011) entitled Can communitybased Tourism Contribute to Development and Poverty Alleviation? Lessons From Nicaragua. This study analyzes and explores how the existence of Communitybased tourism models can support socio-economic development and alleviate poverty through case studies in Nicaragua, Central America. Through exploratory qualitative analysis methods from 6 examples of community-based tourism, surveys and focus group discussions, researchers analyzed the characteristics and effects of different modes. This is then classified based on the impact assessment and analysis of the life cycle. The results showed that the top-down Communitybased tourism model formed by external organizations tended to be less able to develop significantly. While the bottom-up model that comes from the initiative of the local community can actually develop faster and have a positive impact on the 
local economy. Thus it is suggested the need to establish in donating and making policies towards redistribution policies that can strengthen skills, resources, microconditions and family-based entrepreneurship, along with a strong orientation towards the domestic market.

The rapid growth of tourism provides positive opportunities for the workforce. Data from the central body of Bali provincial statistics show that the number of the working-age population in Bali Province in August 2018 reached $3,288,908$ people. Of the working-age population, 76.78 percent $(2,525,355$ people) are the workforce, and 23.22 percent $(763,563$ people) are not the workforce. The workforce in August 2018 increased by 90,905 people (3.73 percent) compared to the force employment in August 2017 (2,434,450 people) or reduced by 81,933 people (3.14 percent) compared to the February 2018 workforce $(2,607,288$ people). The number of people working in Bali in August 2018 reached 2,490,870 people, an increase of 92,563 people (3.86 percent) compared to the status of August $2017(2,398,307)$ or a decrease of 94,073 people (3.64 percent) compared to February 2018, which was 2,584,943 people (source www.bali.bps.go.id). However, tourism has not been able to provide equitable welfare for its people. This is because there is a disparity in income distribution that does not favor the middle to lower classes. The most striking evidence is seen from the income distribution between groups. According to the Bali Central Bureau of Statistics, the percentage of income received by $40 \%$ of the lowest income population in 2013 was $16.32 \%$. This shows the distribution inequality at the moderate level because based on the standards of the World Bank, the income distribution is said to be moderate if the poorest population receives between $12 \%-17 \%$. However, if comparing from the previous year, Bali experienced a significant decline in disparity. It is known that in 2011 Bali was able to position itself in light level inequality, which was at $17.20 \%$, as well as in the past two years, including $22.14 \%$ and $20.75 \%$ in 2009 and 2010 respectively. Even if it relies on the rapid development of tourism, as the biggest contributor, in 2011 expenditure per person per day for foreign tourists reached the US \$ 154.87 or an increase of $5.07 \%$. Similarly, spending per person per day for tourists is Rp. 592,000 or an increase of $17.7 \%$.

This confirms that tourism actually has not helped accelerate poverty alleviation or the impact is not directly significant enough for the welfare distribution. Also, the World Bank in 2000 began to launch the term Communitybased Tourism in order to invite local people to actively participate and be able to enjoy the results themselves. It is this community-based tourism that has until now been increasingly echoed as an effort to alleviate poverty through tourism so that it is hoped that a sustainable symbiosis of mutualism can occur between the two

\subsection{Objectives of the Study}

This study aims to understand, analyze, and discuss how poverty alleviation can be done by increasing community-based tourism development. Specific objectives are described as follows:

1. Knowing the development of community-based marine tourism in Bali

2. Knowing poverty alleviation in the tourism industry and its constraints

3. Knowing the contribution of marine tourism in poverty alleviation

So, it is expected to provide benefits in the form of contributions of thoughts and suggestions to all stakeholders, such as the government, practitioners, 
and the community to synergize and reconsider and optimize tourism implementation and its role in helping alleviate poverty in the coastal area.

\section{METHODOLOGY}

This research is a qualitative exploratory study with documentation studies carried out through observation, as well as the support of secondary data from relevant agencies. The research location is in the village of Pemuteran. Data is then analyzed by Phenomenology theory so that it can explain how this phenomenon can occur and further discuss how the solution should be given

\section{RESULTS AND DISCUSSION}

The results of the research and discussion in this scientific work are described as follows.

Relationship between Tourism and Poverty in Pemuteran Village

Tourism's contribution can no doubt help alleviate poverty. This was expressly expressed by the United Nations World Tourism Organization (UNWTO) in the Global Code of Ethics that:

Recognizing the important dimensions of the role of tourism as an instrument for the alleviation of poverty and the quality of life for all people, its potential to contribute to economic and social development, especially of the developing countries, and its emergence as a vital force for the promotion of international understanding, peace and prosperity

Explicitly, this shows that tourism is a positive instrument for alleviating poverty, which can lead to economic and social development especially for developing countries, and is vital for maintaining harmony and prosperity. Referring to the importance of the role of tourism in achieving the Millennium Development Goals (MDGs), especially on four main target points, including: MDG 1 poverty eradication, MDG 3 Gender equation, environmental sustainability MDG 7 and global alliance MDG 8 for development. This substance is then poured back into the most obvious article on the partisanship of the local community from articles 1,2 and 3, namely Tourism's contribution to mutual understanding and respect between peoples and societies; Tourism as a vehicle for individuals and collective fulfillment; Tourism, a factor of sustainable development.

Based on the statement, then formulated how the real and strategic steps in the form of effective and optimal tourism characteristics in poverty alleviation in UNWTO (2004) are as follows:

1. Tourism activities can go to remote villages and to marginal areas, where most of the poor are located.

2. Economic activities and tourism businesses can be entered by small and medium scale businesses with limited capital and various levels of skills.

3. Tourism activities are also able to encourage the development of other traditional sectors which are mostly cultivated by the poor, such as agriculture and handicrafts. 
4. Tourism activities are labor-intensive so that they can open diverse employment opportunities for the poor, both formal and informal

5. Marginal areas, where the poor lives, maybe rich in tourism resources, so they have a competitive advantage compared to other regions if developed

In trying to realize these traits, steps that can be implemented are also needed to realize the following development of pro-poor tourism by UNWTO (2004):

1. Employment of the poor in tourism businesses

2. Providing goods and services for tourism businesses by the poor or by companies that employ the poor

3. Selling goods and services directly to tourists by the poor (informal economy)

4. Establish and run tourism businesses by the poor, such as small and medium enterprises, or companies based on local communities (formal economy)

5. Taxes and levies on tourism income or profits are continued to benefit the poor

6. Providing or voluntary support by tourism businesses and tourists

7. Investment in infrastructure development driven by tourism must also benefit the poor in their environment, either directly or indirectly or by supporting other sectors.

Referring to what has been formulated by UNWTO, Indonesia also ratified it in accordance with Law No. 10 of 2009 concerning Tourism, in Chapter II Article 4 it has been explicitly explained that the purpose of tourism is one of them is to eradicate poverty, so that this can be used as a reference to always prioritize the poor. Poverty that hit the village community before 2000 became a figurehead and local residents and the government developed Pemuteran village into a community-based tourism village.

\section{Discussion}

Baskoro in Rukendi (2008) explained that conceptually the basic principle of community-based tourism is to place the community as the main actor through community empowerment in various tourism activities, so that the maximum benefit of tourism is for the community. Pitana (2002) adds that the involvement of local communities (community-based approach) is considered as a prerequisite for achieving sustainable tourism development. This is based on the hypothesis that local people already have knowledge in managing natural resources in their area, where this knowledge is based on experiences passed down from generation to generation. In the concept of empowerment, Pitana (2006) requires that there must be three components, including Enabling settings to strengthen the situation of conditions at the local level to be good; Empowering local communities to develop Human Resources (HR) such as improving their knowledge and skills so that they are able to use the settings well; Socio-political support for other supporting devices is in the form of adequate socio-political support.

There are two concepts of Community-based tourism, namely the Topdown where the village is appointed and facilitated by the government, as well as 
bottom-up where the local community itself takes the initiative to develop tourism in the area. In general, Pitana in Amiani (2008) states that community-based tourism must fulfill the following characteristics:

1. Small scale, which uses small-scale financial principles

2. Locally owned \& managed, namely the pursuit of ownership of local communities including management, one example of which is the creation of customary regulations that foreign investors are prohibited from buying land in the village, including by not relying on outside investors to avoid leaking funds

3. Spatial distribution, namely tourism development, which is expected to be able to carry out the principle of participation and equal distribution of development outcomes, especially inter-regional or spatial distribution.

4. Local culture \& culture heritage that is the element of cultural heritage conservation by empowering/developing the culture of local communities through revitalization

5. The locality which is specific/local/ local so that the term local genius appears and local communities are able to provide services/needs for tourists and can even bring creativity in art and lifestyle, so tourists can enjoy something different

6. Quality experience, namely the existence of quality experience because the products offered are of a special nature such as enjoying the life of the village community

7. Authenticity reflects authenticity that is highly sought after by tourists

8. Special niche - market, namely the tendency of foreign tourists to switch from mass tourism to alternative tourism

9. A participatory approach, namely the involvement of local communities to become development goals in community-based tourism development both in planning and implementation, so that all local potential and human resources of local communities are also explored and developed

According to Narayan et al in Budhi (2013) there are four dimensions for defining poverty, namely material dimensions, psychology, access to services and assets / property. Meanwhile, the definition of poverty according to the World Bank is the inability to pay minimal living costs. Poverty can also be seen in relative and absolute terms. Relative poverty is a poor condition because of the influence of development policies that have not been able to reach all levels of society, causing inequality of income distribution, while absolute poverty is determined based on the inability to meet minimum basic needs such as food, clothing, health, housing, and education. work. The Indonesian Ministry of Social Affairs (2013) revealed that Indonesia uses the absolute definition of poverty that is able to compare poverty in general and assess the effects of policies on inter-time poverty reduction programs.

The term community-based tourism became popular since 2000 and was initiated by the World Bank in July 2000 which began to think about how to 
alleviate poverty through the tourism sector. Then, the formula was found in the form of community-based tourism (CBT), which then identified three tourism activities that could support the concept of CBT, namely adventure travel, cultural travel, and ecotourism. This is focused on accommodation in the form of smallfamily owned so that tourism can increase the income of the local community while maintaining and preserving nature, art, socio-culture and lifestyle which are the main attractions of a destination.

As a derivative of CBT, there is a derivative of the tourism development model in the form of Tourism Village. One of the famous tourist villages in Bali is Pemuteran village. Pemuteran village which is a small village on the beach. Pemuteran Beach in Pemuteran Village is popular with natural beauty and calm atmosphere. In Pemuteran Village, as far as the eye can see will be spoiled with natural nuances that are still very natural and air that is free from pollution. Pemuteran village was once a barren village, most of the population worked as fishermen. Narrated in the $80 \mathrm{~s}$, Pemuteran villagers who worked as fishermen used fish BOM to catch fish en masse which did not care about the environment of the coral reef. Then the community leader named I Gusti Agung Prana was aware of the importance of the coral reef environment in Pemuteran Village. Then He taught the public how important the environment for humans, especially the environment under the sea. Thanks to his hard work, people slowly began to realize the way they were wrong in finding fish. Pemuteran village is known as a very beautiful and charming tourist village. Pemuteran village is popular with its exotic and charming beaches with relatively small waves.

Besides, Pemuteran Tourism Village is a model of tourism village in Bali that was developed by applying the concept of ecotourism sustainability based on locality and is a tourist destination with special interests. Not only boosting people's welfare through the economic value of tourism, but the village is also actively implementing efforts to preserve the marine environment which is their wealth. Pemuteran Village is one of the villages developed by the Ministry of Tourism through the Tourism Village program in 2009 - 2010. Support from the program was used to build diving tourism facilities and water tourism around the village. Other tourism support facilities are also available in Pemuteran Village, which currently has 18 homestays / bungalows / inns, 10 hotels / resorts and spas, 5 villas, 20 warungs / restaurants / cafes, 14 diving service companies, and 8 spas / salon

Tourism village development is focused on community capacity building activities aimed at providing business opportunities, creating employment opportunities. In addition, it also fosters the village economy to improve the welfare of the village through the development of homestay, culinary, souvenirs and cultural arts activities. Pemuteran Tourism Village is a tourist village model in Bali which was developed by applying the concept of ecotourism sustainability based on locality and is a tourist destination with special interests. This tourism activity adds to employment opportunities and helps local communities improve their economy.

This special interest tour is illustrated by the Biorock project by building structures from iron which are woven in such a way that they are planted inside the sea as a place to attach coral reefs to breed. The structure is powered by lowpowered electricity, around 6 volts to stimulate the growth of lime in the braid of iron-iron which is very much needed for the growth of coral reefs. The electricity 
flowed does not use electricity from PLN as used by households but by utilizing solar or wind power so that it is more natural. With this method, the growth of coral reefs is six times faster compared to the usual methods of development as well as the recovery ability of growth 20 times faster. One unit of structure to grow coral reefs costs around Rp. 30 million and currently 90 of these structures have been successfully planted. To finance efforts to develop coral reefs, an adoption pattern was adopted, namely that every tourist who visited or other communities could donate Rp. 400 thousand for the development of one coral reef and their names would later be pinned on the reef. The biorock technique has also gained world recognition by obtaining awards such as the PATA Gold Award in 2005 and SKAL International 2003.

Zapata et al. (2011) stated that top-down supportive policies might be useful to drive potential growth towards more sustainable development. More broadly, this also has a good impact on the decline of poor people in Pemuteran villages. In contrast to the top-down, now some regions are beginning to develop themselves by having the initiative to manage the uniqueness of nature and culture as a tourist attraction, this model which is then referred to as bottom-up. Based on the 2014 workshop entitled IPEC (Indonesia Poverty and Empowerment Conference), the villages recognized villages that could develop their regions as independent tourist attractions, including Pejeng Village, Munduk Village and Pemuteran Village. This is also inseparable from pioneers and entrepreneurs who dare to combine local potential and provide access to tourism. One of the motivations of tourists to travel is to enjoy a new atmosphere and the village of Pemuteran is able to fulfill it with unique characteristics in the form of marine tourism with environmental conservation values of marine bio des through bio rock technology.

The number of poor people with a per capita expenditure category per month below the Poverty Line in March 2018 in Bali reaches 171.76 thousand people (BPS Bali Province 2018). Various efforts have been made by the government, especially through the Bali MANDARA program, which is to reduce the expenditure of the poor through social security programs (JKBM, Scholarships and Home Surgery) and to ensure the sustainability of the poor's community through empowering poor communities (Gerbangsadu, Simantri, Jamkrida, PNPM Rural). The success of this government program turned out to be completely incomplete, as seen from the fluctuations in the poor population.

Mass tourism seems to still be the prima donna and the main focus of some tourism actors, no wonder many mass media are more proud of the fantastic number of visits compared to caring about the impact of this tourist invasion. It is this principle which further urges local people to become marginalized and only become supporters, even the severity of the audience of tourism luxury that is developing at this time. Agriculture which used to be the main actor, now only extras are reluctant to be looked at, and actually cause leakage of funds. Luckily, we all quickly awakened to the importance of the synergy of these two actors, namely through the concept titled CBT which promotes the participation of local communities to develop tourism. 


\section{Conclusions}

Tourism has a tremendous impact on socio-cultural, environmental and economic. The contribution of tourism has indeed been recognized worldwide, as revealed by UNWTO that tourism contributes $9 \%$ of total GDP, 1 of 11 jobs worldwide and the key to economic development. Although, there is still a counterproductive effect on tourism and economic conditions. However, the development in community-based tourism villages in Pemuteran Village has been able to improve the welfare of its people.

Such empirical evidence is the main reason for the emergence of the concept of community-based tourism by focusing on how the community itself is the subject of tourism. The basic foundation is because local people know more about their territory and through tourism, the community can get direct income and increasingly preserve environmental and cultural conditions which are important assets of community-based tourist attraction. Thus, tourism which was once accused of causing income disparities and marginalizing local communities is now denied by the presence of community-based tourism that plays a role and becomes an instrument of poverty alleviation.

\section{Suggestions}

Considering there are examples of community-based tourism that have reaped positive impacts, such as Pemuteran Village. This can be used as a positive example for the development of other tourism villages, both from how to manage, market products and distribute their opinions through the synergy and cooperation between tourism actors, the government and traditional kelian. Besides that, the government needs to always supervise and assist the implementation of CBT with top-down models and stimulate villages with lagging categories that have not been touched by tourism to develop a bottom-up model so that community-based tourism will have a positive contribution in alleviating poverty at the village level.

\section{REFERENCES}

Amiani, Nyoman Dini. 2008. "Pengembangan Ekowisata yang Berbasis Masyarakat Menuju Pariwisata Berkelanjutan di Kelurahan Serangan, Bali”. Jurnal Kepariwisataan Indonesia, Vo.3, No.2, hal. 331-339. Jakarta: Pusat Penelitian dan Pengembangan Kepariwisataan

Arieta, Siti. 2010. "Community Based Tourism Pada Masyarakat Pesisir: Dampaknya Terhadap Lingkungan dan Pemberdayaan Ekonomi”. Jurnal Dinamika Maritim, Vol.2, No.1. Tersedia di http://riset.umrah.ac.id/ (Diunduh 27 april 2015)

Asdhiana, I Made. 2013. Lingkungan Pulih, Potensi Bali Membesar. Tersedia di: http://www.balipost.co.id/ (Diunduh 27 april 2015)

Badan Pusat Statistik Bali. 2013. Distribusi Pendapatan Provinsi Bali Menurut Kabupaten/Kota Tahun 2013. Tersedia di http://bali.bps.go.id (Diunduh 27 april 2015)

Badan Pusat Statistik Provinsi Bali. 2014. Jumlah Penduduk Miskin di Bali. Tersedia di http://bali.bps.go.id (Diunduh 27 april 2015) 
Badan Pusat Statistik. 2018. ekonomi-bali-triwulan-iii-2018. Tersedia di https://bali.bps.go.id/pressrelease/2018/11/05/717086/.html diakses 9 Desember 2018

Budhi, Made Kembar Sri. 2013. "Analisis Faktor-faktor yang Berpengaruh Terhadap Pengentasan Kemiskinan di Bali: Analisis FEM Data Panel". Jurnal Ekonomi Kuantitatif Terapan, Vol. 6, No. 1, hal. 1-6. Tersedia di: ojs.unud.ac.id (Diunduh 27 april 2015)

Dinas Pariwisata Provinsi Bali. 2013. Statistik Pariwisata Bali. Denpasar: Dinas Pariwisata Provinsi Bali

Dinas Pariwisata Provinsi Bali. 2014. Jumlah Kunjungan Wisatawan ke Jatiluwih. Tersedia di: www.disparda.baliprov.go.id (Diunduh 27 april 2015)

Kementrian Sosial Republik Indonesia. 2014. Analisis Profil Kemiskinan Nasional. Tersedia di: www.slideshare.net (Diunduh 27 april 2015)

Pemerintah Provinsi Bali Badan Perencanaan Pembangunan Daerah. 2014. Data Bali Membangun 2013. Denpasar: Badan Perencanaan Pembangunan Daerah

Pitana, I Gde. 2002. Apresiasi Kritis Terhadap Kepariwisataan Bali. Denpasar: PT The Works

Pitana, I Gde. 2006. Kepariwisataan Bali dalam Wacana Otonomi Daerah. Jakarta: Puslitbang Kepariwisataan

Rukendi, Cecep dkk. 2008. "Menanggulangi Kemiskinan Melalui Agrowisata dan Wisata Perdesaan yang Berkelanjutan". Jurnal Kepariwisataan Indonesia, Vo.3, No.4, hal. 503-510. Jakarta: Pusat Penelitian dan Pengembangan Kepariwisataan

UNWTO. 2001. Global Code of Ethics. Tersedia di: www.unwto.org (Diunduh 27 april 2015)

UNWTO. 2004. Indicators of Sustainable Development for Tourism Destinations: A Guide Book. Madrid, Spain: WTO

UU No. 10 Tahun 2009 tentang Kepariwisataan

Zapata, M.J et al. 2011. "Can Community-based Tourism Contribute to Development and Poverty Alleviation?" Lessons From Nicaragua. Current Issues in Tourism, Vol. 01, No. 1, pg. 1-25. Tersedia di https://www.academia.edu/ (Diunduh 27 april 2015) 